Article

\title{
Policy Preferences about Managed Aquifer Recharge for Securing Sustainable Water Supply to Chennai City, India
}

\author{
Norbert Brunner ${ }^{1}$, Markus Starkl ${ }^{1, *}$, Ponnusamy Sakthivel ${ }^{1}$, Lakshmanan Elango ${ }^{2}$, \\ Subbaiah Amirthalingam ${ }^{1}$, Chinniyampalayam E. Pratap ${ }^{1}$, Munuswamy Thirunavukkarasu ${ }^{3}$ \\ and Sundaram Parimalarenganayaki ${ }^{2}$
}

1 Centre for Environmental Management and Decision Support (CEMDS), Vienna A-1180, Austria; E-Mails: norbert.brunner@boku.ac.at (N.B.); prof.sakthivel@gmail.com (P.S.); amirtham.alu@gmail.com (S.A.); pratap.erode@gmail.com (C.E.P.)

2 Department of Geology, Anna University, Chennai 600025, India; E-Mails: elango@annauniv.edu (L.E.); sunparimar@yahoo.co.in (S.P.)

3 SPT Consultancy Services, Chennai 600011, India; E-Mail: sptconsultancy@yahoo.co.in

* Author to whom correspondence should be addressed; E-Mail: markus.starkl@boku.ac.at; Tel.: +43-1-47654-5057; Fax: 43-1-47654-5092.

External Editors: Sharon Megdal and Peter Dillon

Received: 4 July 2014; in revised form: 20 November 2014 / Accepted: 26 November 2014 / Published: 3 December 2014

\begin{abstract}
The objective of this study is to bring out the policy changes with respect to managed aquifer recharge (focusing on infiltration ponds), which in the view of relevant stakeholders may ease the problem of groundwater depletion in the context of Chennai City; Tamil Nadu; India. Groundwater is needed for the drinking water security of Chennai and overexploitation has resulted in depletion and seawater intrusion. Current policies at the municipal; state and national level all support recharge of groundwater and rainwater harvesting to counter groundwater depletion. However, despite such favorable policies, the legal framework and the administrative praxis do not support systematic approaches towards managed aquifer recharge in the periphery of Chennai. The present study confirms this, considering the mandates of governmental key-actors and a survey of the preferences and motives of stakeholder representatives. There are about 25 stakeholder groups with interests in groundwater issues, but they lack a common vision. For example, conflicting interest of stakeholders may hinder implementation of certain types of managed aquifer recharge methods. To overcome this problem, most stakeholders support the idea to
\end{abstract}


establish an authority in the state for licensing groundwater extraction and overseeing managed aquifer recharge.

Keywords: managed aquifer recharge (MAR); infiltration ponds; check dams; rainwater harvesting (RWH); Chennai; Tamil Nadu (TN)

\section{Introduction}

In India, as well as in many other countries (e.g., China [1]), overexploitation of groundwater is a serious problem. It has caused declining groundwater levels, deterioration of water quality, and in coastal regions intrusion of seawater. Such a situation may lead to a race for pumping water for irrigation, which accelerates groundwater depletion and ends in a "tragedy of the commons" [2,3]. This becomes evident by higher energy costs for pumping irrigation water: In India, energy for farmers is subsidized (diesel, electricity) or given free and the escalation of subsidies for agriculture burdens government budgets [4].

To overcome groundwater depletion and the associated costs, governments may support managed aquifer recharge (MAR). MAR is the purposeful recharge of water to aquifers for subsequent recovery or environmental benefit, such as rainwater harvesting (RWH), infiltration ponds, or check dams. These are considered in this paper, as they generate water supplies from sources that may otherwise be lost due to runoff [5-8]. MAR also has the aim of preserving or improving groundwater quality. Related groundwater management actions can include substituting alternative water sources for groundwater (the paper considers desalination) and "non-structural policy measures", by which the paper means demand management to promote water conservation (e.g., by water pricing or state sponsored incentive programs to reduce cropping; [9] is an early example).

The basis of this study is a water supply scenario for Chennai, where overexploitation of groundwater has become a threat to drinking water security [7]: "Chronic water shortages mark the norm in this city." Thereby, for the state of Tamil Nadu the legal framework provides a favorable atmosphere for groundwater management, making e.g., RWH on roofs mandatory since 2001. Also present water polices of India are favorable, acknowledging MAR as an important tool for sustaining water supplies for all kinds of users [10]. However, MAR involves multiple agencies, which may not always cooperate or share information [11]. At the same time, there are many different stakeholder groups and their interests in groundwater recharge, groundwater use, or quality of groundwater may not be compatible with each other; rather multiple conflicts of interests (e.g., urban vs. peri-urban and rural) are to be expected [12,13].

Therefore, the paper focuses on the perception of these stakeholder groups on MAR, considering the broader context of groundwater management. It also asks, which policy changes the stakeholders deem necessary to implement a specific MAR approach, namely the construction of many small infiltration ponds. 


\section{Background Information: Current Water Supply and Future Options}

Chennai City (formerly Madras) is the capital of Tamil Nadu state. With 4.7 million people (2011 census) and an area of $426 \mathrm{~km}^{2}$ it is the sixth largest city in India. (Official statistics refer to the old boundaries prior to the expansion of city limits in the year 2011.) With a larger metropolitan area of $1189 \mathrm{~km}^{2}$ and nine million people, it is the fourth largest metropolitan agglomeration in India. The Chennai Metropolitan Water Supply \& Sewerage Board (CMWSSB), a statutory body established in 1978, is responsible for water supply and sewerage functions. It operates in the city, only, but is expected to gradually extend its services to the entire metropolitan area.

Over $90 \%$ of the water supply of Chennai is covered by water stemming from reservoirs, which are depending on the monsoon rains ([14] and Figure 1). When the reservoirs are empty then the water to the city is mostly met by groundwater to cover the gap in water supply. However, due to exploitation of the groundwater resources (pumping of groundwater for domestic, industrial and agricultural water supply), the contribution of groundwater to the water supply of Chennai has diminished, from a maximum of $25 \%$ to around $6 \%$ during 2000. At the beginning of the 2013 summer season (March 2013) the share of groundwater was as low as $1 \%$ [14]. This indicates over-dependence on all current sources to meet Chennai's water supply. Further, the decline of the groundwater level has led to the intrusion of seawater in the coastal area.

Figure 1. Reservoirs around Chennai.

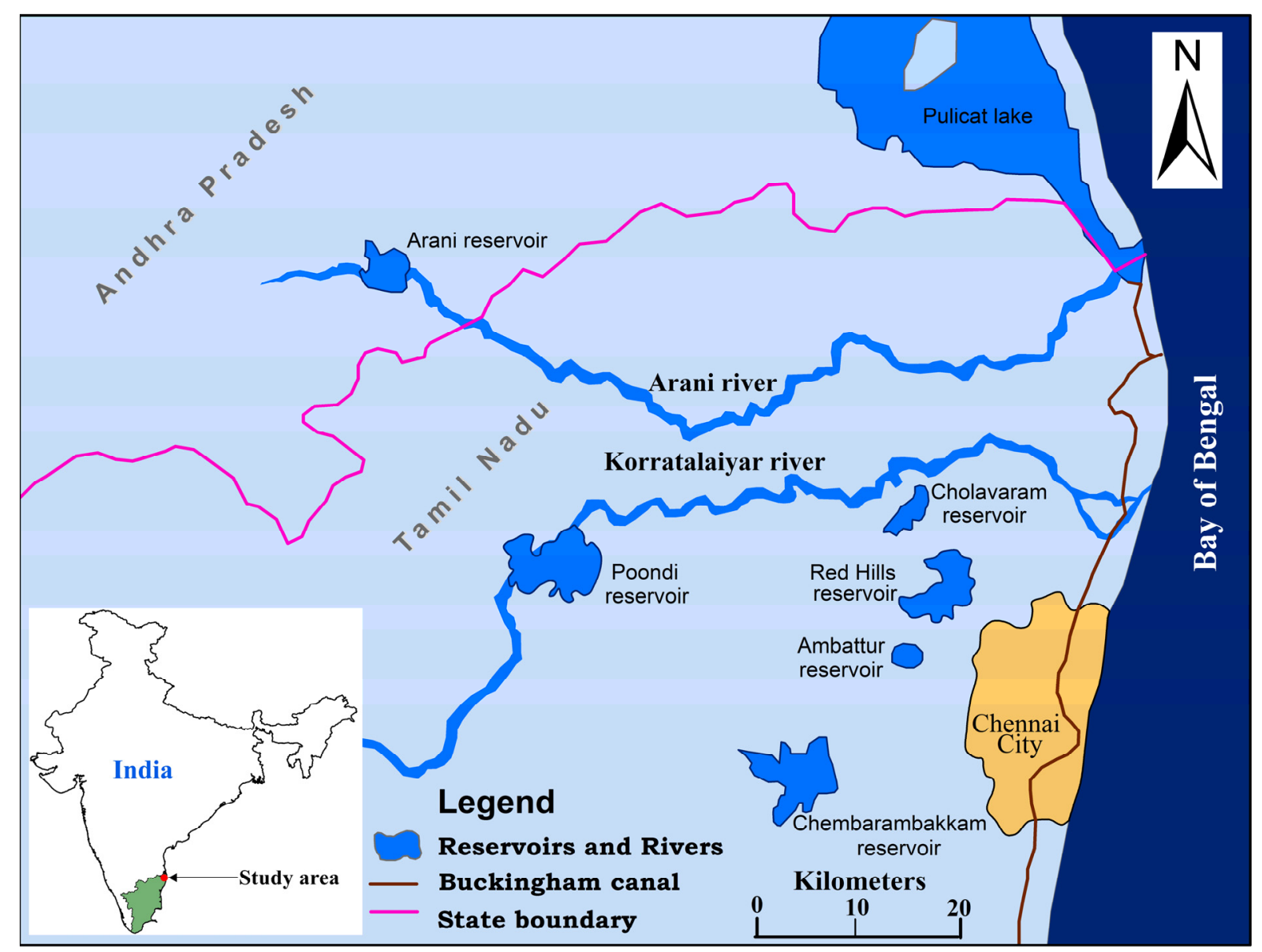


Conventional technical approaches to overcome the water shortages during summer were the construction of new reservoirs (e.g., Veeranam Lake Water Supply Project, commissioned in 2004), the increase of the capacity of existing reservoirs, and the provision of desalination plants. The Telugu Ganga Project diverts water from Krishna River in Andhra Pradesh to Chennai. Also, water pricing is practiced; however, in comparison with other cities such as Bangalore and Hyderabad only few households have functioning meters [15].

In addition, MAR has been practiced to replenish the aquifer and to mitigate seawater intrusion. Thereby, MAR was considered for replenishing the local aquifer at acceptable costs in order to "build a credit that can be drawn on in drought" [16]. Indeed, mitigation of seawater intrusion by MAR in the aquifers north of Chennai was observed by [17]. Thereby, in Tamil Nadu State RWH in all buildings is mandatory. Further, there has been a popular movement for the revival of traditional structures, e.g., Oorani for RWH or temple tanks for groundwater recharge. Two other technologies for MAR have been implemented: check-dams and infiltration ponds.

With respect to infiltration ponds there is one pilot study, implemented by Anna University. To be effective, a large number of small ponds would be required and a preliminary survey has shown that around 10,000 percolation ponds are feasible in the Arani and Koratallai river basin north of Chennai. Initial results indicate that approximately $40 \%$ of water stored in an infiltration pond may be recharged.

Similar figures about recharge were published for check dams [18]. Their overall storage capacity shall be 31 million $\mathrm{m}^{3}$, with capacities ranging from 0.2 to 2.87 million $\mathrm{m}^{3}$. Currently, there are nine dams at Arani River (4.42 million $\mathrm{m}^{3}$ ), seven at Kortallai River (3.4 million $\mathrm{m}^{3}$ ) and three at Palar River (5.18 million $\mathrm{m}^{3}$ ). At Arani and Kortallai Rivers $71 \%$ of the planned capacity is implemented. Check dams at Palar River have lower priority, as the city depends only in extreme droughts on water from that river basin, which is at a distance of about $80 \mathrm{~km}$.

Table 1 informs about the costs of recent projects.

Table 1. Capital costs for water supply infrastructure.

\begin{tabular}{|c|c|c|c|}
\hline Infrastructure & $\begin{array}{l}\text { Water Supplied/Recharged } \\
\text { (Million } \mathbf{~ m}^{3} / \text { year) } \\
\end{array}$ & $\begin{array}{l}\text { Capital Costs } \\
\text { (Million INR) }\end{array}$ & $\begin{array}{l}\text { Unit Costs } \\
\left(\mathrm{INR} / \mathbf{m}^{3}\right)\end{array}$ \\
\hline $\begin{array}{l}\text { New surface storage reservoirs } \\
\text { (Thervoikandigai-Kannankottai Reservoir) }\end{array}$ & 28.31 & 3300 & 117 \\
\hline $\begin{array}{l}\text { Increasing storage capacity of existing reservoirs } \\
\text { (Cholavaram, Porur, Ayanambakkam \& Nemam tanks) }\end{array}$ & 16.08 & 1300 & 81 \\
\hline Desalination (Nemmeli plant) & 36.50 & 8712 & 239 \\
\hline New check dam (Irulipattu check dam) & 0.30 & 62 & 207 \\
\hline Infiltration pond (Anna University pilot project) & 0.000175 & 0.015 & 86 \\
\hline
\end{tabular}

Note: Data are drawn from project reports. These values were considered suitable for initiating discussion on stakeholder opinions, but should not be relied on for estimating actual costs of the respective types of infrastructure.

\section{Problem and Goal}

This paper studies stakeholder perceptions in Chennai about groundwater management. It compares their views about three MAR options (roof top RWH in urban areas, large check dams and small infiltration ponds) with other approaches to overcome the problem of groundwater depletion due to 
over-exploitation, such as conventional infrastructure solutions (building or enlarging reservoirs), desalination, and non-structural policy instruments (e.g., water pricing). With respect to these options, the paper presents the interests, preferences and motivations of representatives of stakeholders at the national, state, municipal and individual levels, who took part in two workshops.

\section{Method}

A preliminary study identified the most relevant local stakeholders, in particular the governmental key-actors with interests in groundwater use, recharge, and quality (Table 2). Subsequently, the perceptions and preferences of stakeholder representatives for about six options to secure the future water supply for Chennai were explored, based on two workshops. Stakeholders interested in the topics (first workshop about options to secure water supply for Chennai, second workshop about infiltration ponds) were contacted and invited to participate. Thereby, "stakeholders" at the national, state or municipal levels are government agencies involved in water governance, while at the local and individual level these are groups of persons, companies or organizations in the Chennai area with a concern for groundwater related issues.

Table 2. List of stakeholders.

\begin{tabular}{|c|c|c|}
\hline Stakeholder/Institution & Level & Abbreviation \\
\hline Government of India, Ministry of Water Resources, Planning Commission & & GoI \\
\hline Central Pollution Control Board & & $\mathrm{CPCB}$ \\
\hline Central Groundwater Board & National (Union State) & CGWB \\
\hline Coastal Aquaculture Authority & & CAA \\
\hline National Green Tribunal & & NGT \\
\hline State Government of Tamil Nadu & & GoTN \\
\hline Public Works Department & & TNPWD \\
\hline Pollution Control Board & & TNPCB \\
\hline Water Supply \& Drainage Board & Tamil Nadu State & TNWSDB or TWAD \\
\hline Town \& Country Planning Board & & TNTCPB \\
\hline Hindu Religious \& Charitable Endowment Board. & & TNHRCE \\
\hline Water Resources Regulatory Authority (proposed) & & TNWRRA \\
\hline Chennai City Municipal Corporation & & $\mathrm{CCMC}$ \\
\hline Chennai Metropolitan Development Authority & Municipality & CMDA \\
\hline Chennai Metropolitan Water Supply \& Sewerage Board & & CMWSSB \\
\hline Food and mining industry & & Industry \\
\hline Private water companies & & WaterBus \\
\hline Tanker truck operators & & Tanker \\
\hline Water users associations & & WUA \\
\hline Agriculture sector & Local & Farmers \\
\hline Peri-urban villages & non-governmental & Peri \\
\hline Peasants without own land & & Workers \\
\hline Residents of the city & & Residents \\
\hline Organizations of civil society & & CSOs \\
\hline Research centers and universities & & Acad \\
\hline
\end{tabular}


A first workshop was conducted with participants from government and civil society. Also, several members of the project team took part and informed the participants about the present situation (see background information in Section 2).

In particular, respondents were informed about the technical options and costs observed for recent projects (Table 1): Increasing the capacity of existing reservoirs and groundwater recharge by infiltration ponds are most economical. The subsequent plenary discussions focused on the legal situation and on implementation aspects. At the end of the workshop, 25 respondents answered a questionnaire about the opinions concerning different groundwater management approaches, about the relevant criteria to assess these approaches, and about the opinions concerning different policy approaches.

The output of this workshop was used for the subsequent discussion of the legal and policy issues of implementing infiltration ponds in the area surrounding Chennai, mapped in Figure 1.

The project team presented these results at another workshop with representatives from government organizations and civil society. Again, at the end of the workshop 29 questionnaires were answered. (Respondents of the survey at the first workshop did not take part.) In addition to the previous questions about groundwater management approaches and criteria to assess them, a set of questions inquired specifically about infiltration ponds as well as legal and policy issues to implement them.

Participants of the workshops came from stakeholders groups, who could be decisive for MAR implementation. For the government (Table 2 for the abbreviations), these were members of the Chennai branch of CGWB for the central government; from Madras High Court for the jurisdiction, from several government departments (e.g., TNWSDB, Chennai, TNPWD, Chennai) of Tamil Nadu State; and from CMWSSB, Chennai, for the city. From civil society, there were representatives from business (e.g., consultants, advocates), NGOs (e.g., Alacrity Foundation, Chennai, DHAN Foundation, Chennai), and students and scientists from research institutions (e.g., Anna University, Chennai, Tamil Nadu Dr. Ambedkar Law University, Chennai). At both workshops, farmers took part, whose land might be used for MAR structures.

The surveys were conducted in the context of the future water supply needs of Chennai. For the interpretation, it should be recalled that the surveys were not intended to be representative opinion polls for any specific group, and no concrete decision should be prepared. Rather, these were explorative studies, where samples of 10-30 respondents suffice [19].

In particular, the sample was not representative for the population at large: $11 \%$ were women and the median age was 51, ranging from 20 to 37 for women and 25 to 71 for men. Further, $38 \%$ were from government or courts, 15\% from research institutions, $19 \%$ experts from (other) NGOs, and $27 \%$ were farmers, some without education. To ensure their inclusion and to avoid misunderstandings of the questions, members of the project team (they did not take part in the survey) assisted the respondents in filling the questionnaires.

In order to identify explanatory structure, the survey data were processed by methods of pattern recognition, data mining, and social network analysis, using preferably non-parametric tests suitable for small sample sizes. The significance level was uniformly $95 \%$ (with the Bonferroni correction for significance of multiple comparisons, e.g., Milton Friedman's test). For one-sided 95\% confidence intervals, Clopper-Pearson method (based on the inverse beta-distribution) was used, as it is conservative (higher confidence than stated as the nominal level). Software used was Microsoft Excel, XL-STAT of Addinsoft for statistical tests and data mining (an add-in to Microsoft Excel) and UCINET 6 of 
Analytic Technologies for social network analysis. In future decision making and project planning, accommodating and acknowledging stakeholder input and feedback will be important for a successful implementation and these methods may be applied again for such analysis.

\section{Results}

\subsection{Stakeholder Survey}

This section lists 25 stakeholders (Table 2) and summarizes their interests in groundwater issues (Figure 2).

Figure 2. Stakeholders and their groundwater-related interests.

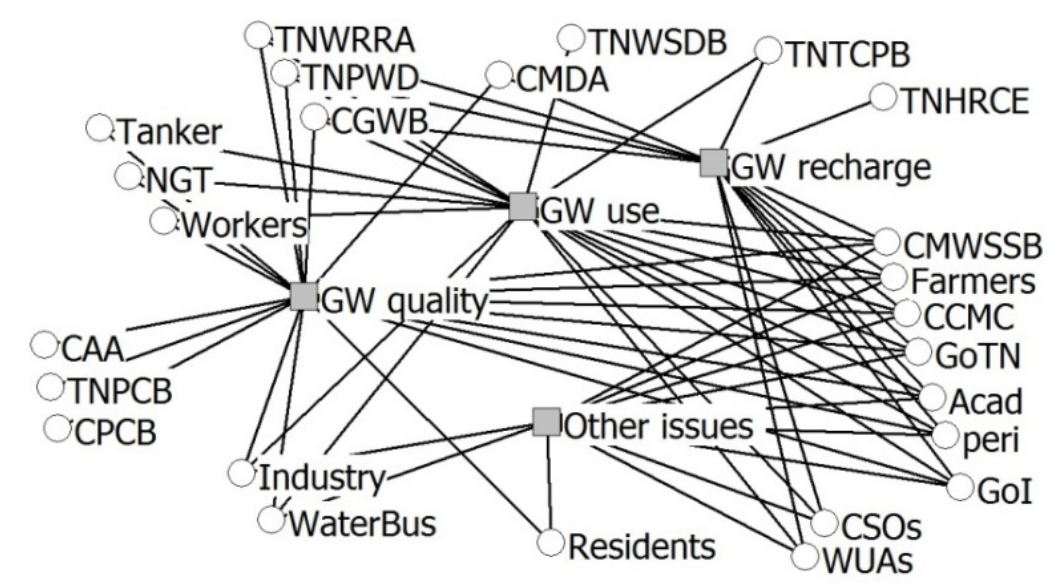

Notes: (2-mode network, using UCINET 6): Grey squares are groundwater-related interests; "GW quality" = pollution control of groundwater, "GW use" = extraction of groundwater, "GW recharge" = RWH or other MAR infrastructure, "Other issues" = water saving by the use of recycled water or similar questions. White circles represent stakeholders (abbreviations explained in Table 2), whereby lines connect stakeholders to their interests.

For governmental stakeholders, the interests are defined from the mandate (i.e., laws and policies). For instance, as GoI delegated to the states groundwater responsibilities [20], and as the municipalities are responsible for actual water provision, at all levels of government there is an interest in all groundwater issues. More specialized government institutions have more restricted interests (Figure 2).

For institutional non-governmental local stakeholders (companies, universities, water user associations and other organizations), interests in groundwater issues, also indirect ones (e.g., industry, with direct interest in groundwater extraction, but not necessarily in recharge), were inferred from their business, research or other activities. For instance (with respect to CSOs), media regularly inform the public about the depletion of groundwater and sea water intrusion, and about advantages of groundwater recharge. The same is true for certain NGOs, such as local groups against sale of groundwater in the villages around Chennai [21].

For groups of individual stakeholders (e.g., farmers, peasants, residents), the interests were figured out from their needs. 


\subsection{Comparing Acceptance for Water Supply Options}

The results of this subsection are based on two stakeholder workshops and the subsequent surveys with 54 responses, of which 50 could be used, as all relevant questions were answered.

Stakeholders were asked about the acceptance of six approaches: increasing the capacity of reservoirs (representative of conventional approaches), desalination, non-structural policy instruments (such as water pricing), and MAR through RWH, check dams, and infiltration ponds. The options were chosen, because they were practiced or considered in the political discourse in the context of water saving and recovery, drinking water security, and groundwater recharge. (RWH is mandatory, reservoirs, desalination, and check dams are common, infiltration ponds and water pricing are discussed.) Further, they are typical instruments for different policy and technology approaches, and they operate at different scales.

Respondents were asked to assess the potential of the different options for securing the water supply (very high, high, low, very low) and to rank the options in terms of their individual preferences (from $1=$ highest preference to $6=$ lowest), using the "1224 competition ranking" (rank function of Microsoft Excel) to handle equals. From these answers, low acceptance $(-1)$ of an option for a stakeholder was defined, if it was of low or very low potential and the ranking was five or six, and high acceptance $(+1)$ was defined symmetrically (high or very high potential and rank one or two); the other answers were interpreted as indifference (0).

Summarizing the confidence intervals (Table 3), except for desalination plants and non-structural policies with low acceptance for at least $1 / 4$ of stakeholders, all other options appeared to be acceptable. Infiltration ponds were neither strongly supported, nor disliked by many.

Table 3. One-sided 95\% Clopper-Pearson confidence intervals for acceptance of options.

\begin{tabular}{cccccc}
\hline \multirow{2}{*}{ Option } & \multicolumn{2}{c}{ High Acceptance } & & \multicolumn{2}{c}{ Low Acceptance } \\
\cline { 2 - 3 } \cline { 5 - 6 } & Lower & Upper & & Lower & Upper \\
\hline RWH & $34 \%$ & $59 \%$ & & $0 \%$ & $6 \%$ \\
Enlarge Reservoirs & $34 \%$ & $59 \%$ & & $3 \%$ & $17 \%$ \\
Check Dams & $38 \%$ & $62 \%$ & & $4 \%$ & $20 \%$ \\
Infiltration Ponds & $13 \%$ & $34 \%$ & & $1 \%$ & $12 \%$ \\
Desalination & $14 \%$ & $36 \%$ & & $34 \%$ & $59 \%$ \\
Non-Structural Policies & $2 \%$ & $15 \%$ & & $28 \%$ & $53 \%$ \\
\hline
\end{tabular}

Comparing also the distribution of the acceptance levels of each two options (Figure 3), desalination and policies had with 95\% significance stochastically lower acceptance than RWH, building new check dams or enlarging reservoirs. For infiltration ponds (37 indifferent respondents) there were no significant differences in acceptance to any other option. 
Figure 3. Pair-wise tests for differences in acceptance.

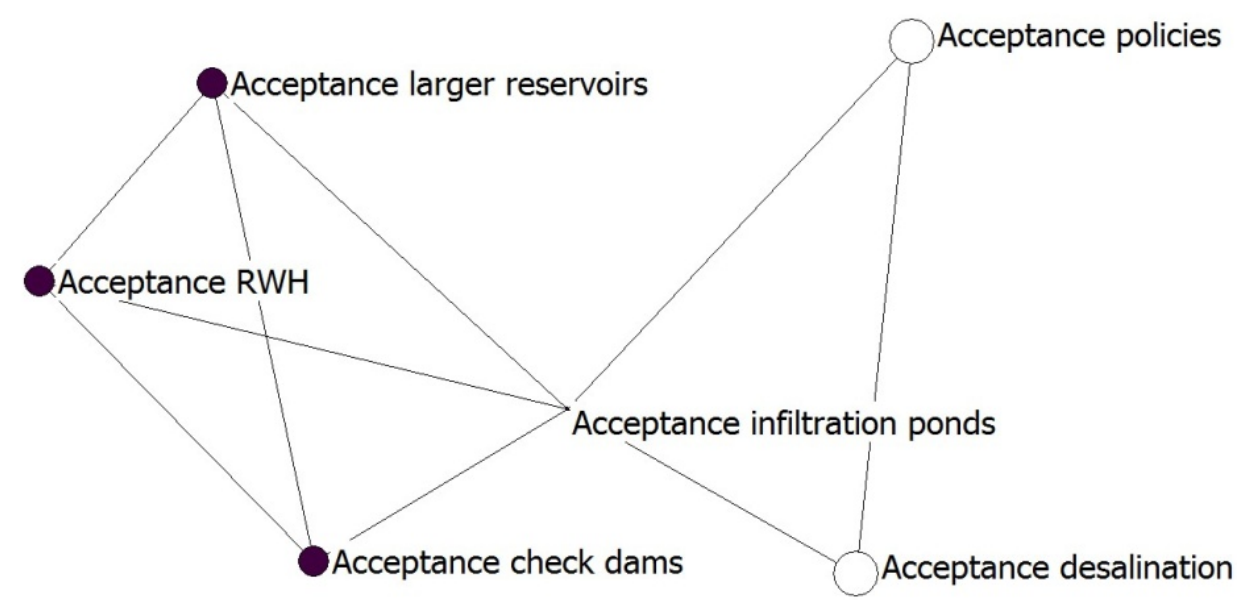

Notes: Based on 50 responses, nodes represent options for securing water supply and links indicate, that "there is no $99.7 \%$ significant difference by Friedman's test", as computed with XL-Stat (correcting significance for 15 pair-wise comparisons). Colors identify two K-cores (clique-like structures) and node size is by closeness (a measure of centrality, which identifies far-off and thus rather different options), as computed with UCINET 6. The positions indicate lower acceptance to the right.

\subsection{Stakeholder Motivations}

The results of this subsection are based on two stakeholder workshops with 54 respondents.

Again, from 54 responses 50 were used, as they answered all relevant questions. To explore the motivation, respondents were asked to rank key-criteria by importance. As expected, on average human health (water quality) was most important, followed by the impact on the environment, social aspects (equity), impact on economy (costs, development), and practical issues (implementation, readiness of institutions). While between two consecutive criteria (e.g., health and environment) the difference was not significant, the criterion after the next one (e.g., social compared to health) had a stochastically higher (i.e., worse) rank for importance (Friedman's test at 99.5\% significance to correct for 10 pair-wise comparisons).

The 50 responses that answered all questions about the ranks of criteria and about the potentials, ranks, and acceptance of options were positively correlated, which indicates some consensus amongst respondents. A cluster analysis based on high correlations identified 22 respondents ("cluster respondents") with similar views (Figure 4). However, it also singled out 28 "non-cluster respondents", of them 22 idiosyncratic (no high correlation to any other response) and six almost idiosyncratic (highly correlated to only one other response). Regression trees (using XL-Stat) characterized the cluster-preferences (see [22] for atypical responses): Typically, 91\% of the cluster respondents (20 of 22) had low acceptance for desalination and they ranked health first or second. Non-cluster respondents were expected to be more diverse, but typically, $68 \%$ of the non-cluster respondents (19 of 28) were indifferent or positive (high acceptance) about desalination and indifferent or negative (low acceptance) about check dams. 
Figure 4. Cluster analysis of respondents to identify consensus.

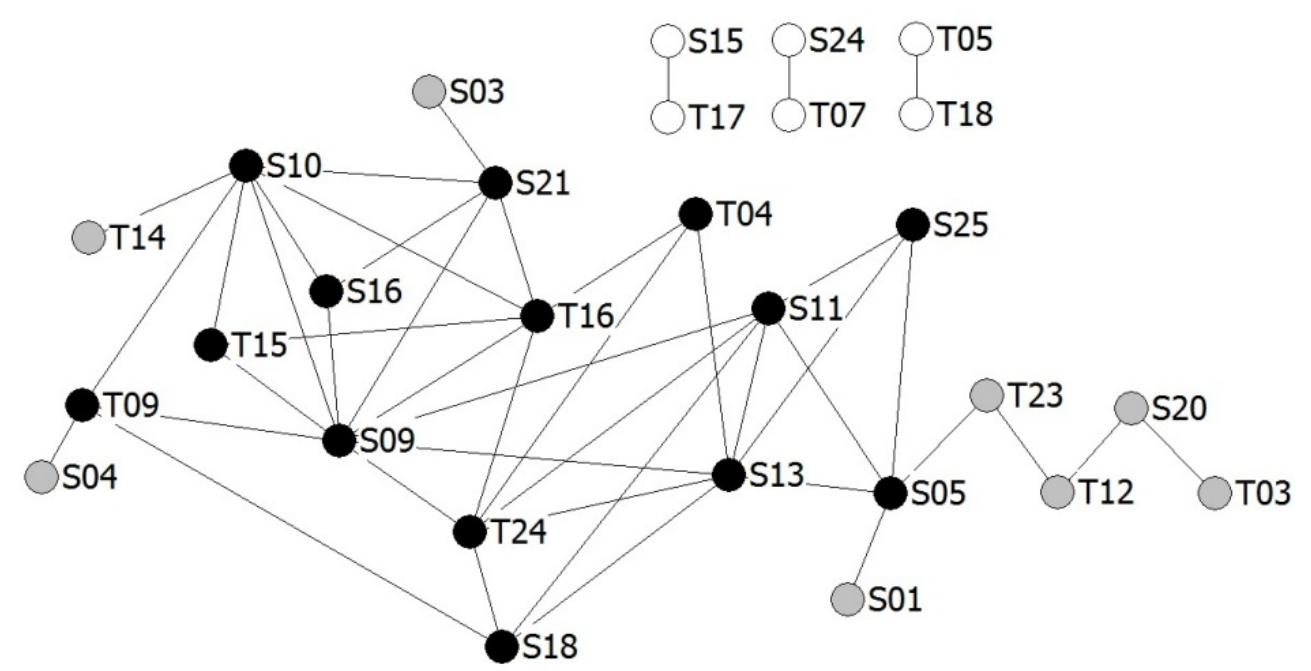

Notes: Nodes labeled S and T denote participants of the first and second workshops respectively. Based on the preferences for options (potential, rank, and acceptance) and criteria (importance rank), for each pair of responses the correlation coefficient was computed. Links indicate a $99.99 \%$ significant positive correlation coefficient of 0.9 or higher between responses ( $T$-test, XL-Stat). For the figure, 22 isolated responses were removed (not highly correlated to any other response) and for six (white) nodes there is a link to one other node only. The remaining 22 nodes identify "cluster respondents" with similar views. Within this group, 14 black nodes represent a K-core (a clique like structure), of them $50 \%$ farmers, and 8 grey nodes peripheral respondents; they would be disconnected upon removal of a node (computations with UCINET 6).

\subsection{Views on Legal Regulations and Policy Instruments for Implementing Infiltration Ponds}

The results of this subsection are based on the second workshop.

For Table 4, 24 of 29 respondents answered all relevant questions (five did not). The workshop focused on the stakeholder views concerning the implementation of infiltration ponds, as in the view of the project team building thousands of small infiltration ponds would be an economically viable response to groundwater depletion, where the social group with the largest consumption of groundwater, the farmers, assume responsibility for its recharge.

Table 4 summarizes the views and displays significant differences between cluster and non-cluster respondents. The majority of respondents was critical about water supply, supported "the proposal to construct thousands of infiltration ponds in agricultural areas around Chennai" (interview question), whereby the farmers should take the initiative to implement them, the government should finance a substantial share of the construction costs, and farmers should operate and maintain their infiltration ponds and be responsible for the running costs (i.e., for operation and maintenance). As to the differences between cluster and non-cluster respondents displayed in Table 4, cluster respondents have seen more responsibility in all aspects with the farmers.

For Table 5, the acceptance for instruments that support implementation of infiltration ponds was explored on the basis of 26 responses at the second workshop. (Three of 29 respondents did not answer all respective questions.) Thereby, the acceptance for policies was defined from the answers about the suitability (suitable, rather suitable, rather not suitable, not suitable) and the rank $(1=$ highest to 
5 = lowest preference; respondents could propose as fifth category "other") of the policy instruments: High acceptance means suitable and rank one or two, low acceptance means not suitable and rank four or five. Table 5 displays the acceptance. ("Other" is not displayed, as only 7 of 26 respondents considered it.) Summarizing, two policy instruments to promote infiltration ponds were acceptable: supporting ponds using public funds and providing information. Thereby, "information" was discussed in a broader context of a (participative) communication strategy, as outlined e.g., by [23]. Making infiltration ponds mandatory for farms with more than one acre (about $4000 \mathrm{~m}^{2}$ ) may be contested, with up to $32 \%$ opponents (not so much farmers) and up to $56 \%$ supporters. Rather not acceptable was fining farmers, who do not have infiltration ponds.

Table 4. One-sided 95\% Clopper-Pearson confidence intervals for stakeholder views.

\begin{tabular}{|c|c|c|c|c|}
\hline \multirow{2}{*}{\multicolumn{2}{|c|}{ Question }} & \multicolumn{2}{|c|}{ Approval } & \multirow{2}{*}{ Cluster Difference } \\
\hline & & Lower & Upper & \\
\hline 1. & Water Supply: improvements needed & $88 \%$ & $100 \%$ & $\mathrm{NC}>\mathrm{C}$ \\
\hline 2. & Infiltration ponds: want them & $71 \%$ & $97 \%$ & No \\
\hline 3. & Policies \& laws support infiltration ponds & $52 \%$ & $85 \%$ & No \\
\hline 4. & Farmers should drive pond development & $32 \%$ & $68 \%$ & $\mathrm{NC}<\mathrm{C}$ \\
\hline 5. & Government should drive pond development & $21 \%$ & $56 \%$ & No \\
\hline 6. & Taxpayer should drive pond development & $0 \%$ & $12 \%$ & No \\
\hline 7. & Consumers should drive pond development & $3 \%$ & $29 \%$ & No \\
\hline 8. & Others should drive pond development & $6 \%$ & $34 \%$ & $\mathrm{NC}>\mathrm{C}$ \\
\hline 9. & Farmers should pay pond construction & $11 \%$ & $43 \%$ & No \\
\hline 10. & Government should pay pond construction & $40 \%$ & $75 \%$ & $\mathrm{NC}>\mathrm{C}$ \\
\hline 11. & Taxpayer should pay pond construction & $6 \%$ & $34 \%$ & $\mathrm{NC}<\mathrm{C}$ \\
\hline 12. & Consumers should pay pond construction & $0 \%$ & $18 \%$ & $\mathrm{NC}<\mathrm{C}$ \\
\hline 13. & Others should pay pond construction & $3 \%$ & $29 \%$ & $\mathrm{NC}>\mathrm{C}$ \\
\hline 14. & Farmers should pay O\&M of ponds & $44 \%$ & $79 \%$ & $\mathrm{NC}<\mathrm{C}$ \\
\hline 15. & Government should pay O\&M of ponds & $6 \%$ & $34 \%$ & $\mathrm{NC}>\mathrm{C}$ \\
\hline 16. & Taxpayer should pay O\&M of ponds & $3 \%$ & $29 \%$ & $\mathrm{NC}<\mathrm{C}$ \\
\hline 17. & Consumers should pay O\&M of ponds & $0 \%$ & $18 \%$ & $\mathrm{NC}>\mathrm{C}$ \\
\hline 18. & Others should pay O\&M of ponds & $3 \%$ & $29 \%$ & $\mathrm{NC}>\mathrm{C}$ \\
\hline 19. & Farmers should operate ponds & $61 \%$ & $91 \%$ & $\mathrm{NC}<\mathrm{C}$ \\
\hline 20. & Government should operate ponds & $3 \%$ & $29 \%$ & $\mathrm{NC}>\mathrm{C}$ \\
\hline 21. & NGOs should operate ponds & $0 \%$ & $18 \%$ & $\mathrm{NC}>\mathrm{C}$ \\
\hline 22. & Others should operate ponds & $0 \%$ & $18 \%$ & $\mathrm{NC}>\mathrm{C}$ \\
\hline
\end{tabular}

Notes: Respondents could answer yes/no $= \pm 1$, and yes/no with reservations $= \pm 0.5$. "Approval" gives one sided $95 \%$ confidence intervals for the percent answering yes or yes with reservations. "Cluster difference" informs, if with $99.99 \%$ significance (Mann-Whitney test) respondents of one cluster had a stochastically higher/lower approval and different mean approval rates.

Table 5. One-sided 95\% Clopper-Pearson confidence intervals for acceptance of policies.

\begin{tabular}{ccccc}
\hline \multirow{2}{*}{ Policy Instrument } & \multicolumn{2}{c}{ High Acceptance } & \multicolumn{2}{c}{ Low Acceptance } \\
\cline { 2 - 5 } & Lower & Upper & Lower & Upper \\
\hline Public support for ponds & $33 \%$ & $67 \%$ & $0 \%$ & $17 \%$ \\
Information about ponds & $26 \%$ & $60 \%$ & $0 \%$ & $17 \%$ \\
Mandatory ponds (farms: 1 + acre) & $23 \%$ & $56 \%$ & $5 \%$ & $32 \%$ \\
Fine farmers without a pond & $0 \%$ & $11 \%$ & $23 \%$ & $56 \%$ \\
\hline
\end{tabular}


As the questions to identify needs for legal and policy changes were more specialized, respondents of the second workshop skipped certain questions depending on the expertise. (For this set of questions, $7 \%$ of 667 entries, i.e., 29 responses to 23 questions, were not answered). The following percentages refer to those respondents that answered the respective questions.

(1) For the question, as to what institution should play an active role in groundwater conservation, most responsibility should rest with the State Government (48\% stated that it would be the most important institution), municipal governments (for $48 \%$ it was the second most important institution) and farmers (for 33\% the third most important group). Further, the State Government had (at 95\% significance) stochastically higher priority than the Union Government (for 35\% less important than the above actors or civil society/NGOs).

(2) For the question, as to whom governments should hear, when drafting and implementing water policies, farmers (for $68 \%$ the most important group to be heard) had with $95 \%$ significance a stochastically higher priority than all groups, except civil society (for $44 \%$ the second most important group). Surprisingly, courts (for 52\% least important of all groups, except "other") had with $95 \%$ significance a stochastically lower priority than civil society and farmers.

(3) Most respondents (66\%) considered the current situation as supportive for infiltration ponds and overall the present groundwater recharge measures in Chennai would be adequate $(50 \%)$. However, in view of the discussion at the workshop with respect to MAR, 59\% answered that the current groundwater law was not adequate (see Section 5.5).

(4) With respect to groundwater-related institutions, 79\% wished a law resembling the Tamil Nadu Groundwater Development and Management Act of 2003, which was never notified and finally repealed in 2013 (Groundwater Development and Management Repeal Ordinance). That Act would have foreseen an authority (TNWRRA) for MAR and Madras High Court repeatedly urged the state to notify it [24]. However, only certain aspects of this act were preserved in the form of Government Orders.

(5) Further, 69\% would also approve of a law similar to the Model Bill for the Conservation, Protection and Regulation of Groundwater. This draft bill by the National Planning Commission of India is favorable for MAR.

(6) With respect to the characteristic features of these proposals, 78\% support the establishment of a state authority responsible for water allocation. If there were such an authority, its agenda should include for $84 \%$ the regulation of groundwater extraction and for $79 \%$ the stipulation of MAR measures.

(7) Further, for $93 \%$ of respondents, a new groundwater law should be effective against encroachers who endanger groundwater. For $86 \%$ the legal regulations should be specific for regions with respect to MAR. 90\% support stricter pollution control, where the local situation requires this. For $82 \%$ land utilization policies should be based on water availability.

\subsection{Specific Observations from the Workshop Discussions}

Compared to the other options, "non-structural policy instruments" was atypical, as it describes a bundle of policy instruments. In the workshops, the project team explained that this would include e.g., water pricing, banning or licensing of groundwater extraction, enforcing or supporting change to less 
water demanding crops, enforcing or supporting summer plowing to maintain soil humidity, or merely awareness rising amongst different target groups for issues related to water saving. However, perhaps as water pricing is practiced in Chennai (see Section 2), the discussions focused on "reducing demand by higher drinking water or irrigation water prices". Thus, for this paper "non-structural policy instruments" de facto means "water pricing and measures supporting it" (e.g., cut of energy subsidies, privatization).

For the other options, no such problems occurred. Further, although respondents of the first workshop added several proposals for mitigating water scarcity, these proposals were conceptually similar to the considered options. Amongst the proposals was metering in apartment complexes and big hotels; control of demand by licensing; to encourage water saving toilets; recycling of grey water for domestic purposes (toilet flush); to simplify water recycling by separating wastewater according to its sources; clearing silt and sand from existing ponds to help sustain groundwater recharge; recharging storm-water and treated wastewater. Other suggestions were interlinking the rivers of Chennai and transporting water from distant sources.

For the criteria, additional questions (at the first workshop only) indicated that in applying the criteria to specific options, respondents lacked a common understanding about the meaning of the criteria. For instance, with respect to health, some approved of desalination, as it provides clean water, while others disapproved, as it does not provide natural water, which they perceived as healthy. Also for RWH, some were concerned about possible contamination, if collected rainwater was used for drinking, while others focused on other domestic uses and were not concerned. Similarly, for reservoirs and to a lesser extent for infiltration ponds, some were concerned about risks due to water contamination and dumping of waste.

In view of these experiences, the second workshop on infiltration ponds elaborated more on these criteria. However, with respect to the preferences there were no significant differences between the workshops, except for RWH: Participants of the second workshop had with $95 \%$ significance a stochastically higher acceptance for RWH than those of the first workshop (but at both workshops it was highly accepted). Perhaps, this was due to the focus of the second workshop on infiltration ponds, which are conceptually similar (small decentralized systems) to RWH.

For the legal situation, although by Table 3, RWH had highest support and least opposition, and at both workshops there was substantial criticism. Some stakeholder representatives disapproved of the mandatory implementation of RWH in every building without taking note of the different geological patterns, the different capacity of the ground to hold water, different rainfall patterns and complex groundwater usage. Stakeholder representatives of the second workshop therefore asked that regulations should allow considering the local situation (point 7 in Section 5.4).

These concerns about the consideration of the local situation apply also to the other options: If e.g., laws were requiring all farmers to build infiltration ponds, under certain circumstances such ponds may be meaningless.

Further, stakeholders reported implementation problems, as due to understaffing CMWSSB barely communicates with the public and lacks support from other stakeholders. This in turn results in deficient law enforcement: RWH structures are routinely monitored and maintained only in exceptional cases. Hence, stakeholders asked for more regular monitoring.

Similar implementation problems made current groundwater laws (point 3 in Section 5.4) inadequate: While CMWSSB denies groundwater extraction licenses for commercial purposes, the registration of 
wells largely failed and unauthorized extraction of groundwater is prevailing throughout the city; the offenders enjoy impunity.

\section{Discussion}

The stakeholder surveys confirmed the known fact that a substantial fraction of stakeholder representatives was skeptical about desalination plants, which are amongst the most costly options to secure drinking water supply. Such low acceptance for desalination plants is known also from other countries, e.g., Australia [25]. In India cultural issues (also for educated populations, only spring water may be perceived as clean and healthy) aggravate this low acceptance problem.

The observed low acceptance of non-structural policies may be explained by the critical discussion of water pricing and privatization of water services. These policies are perceived critically also in other countries, e.g., Bolivia, where increases of tariffs have stirred violent public protests [26], Ghana and Tanzania [27], or South Africa [28]. There are concerns about environmental justice, as the burdens for the poor could be out of proportion [29].

Also, the high acceptance for RWH was as expected, as RWH is a traditional water supply option supported also by court judgments that repeatedly confirmed the eviction of encroachers from land used for RWH [30]. However, stakeholders had doubts about the efficient functioning of RWH structures.

The conventional approach to secure water supply is building new reservoirs. The stakeholder views on this option were not inquired, as there are limitations to new reservoirs, and to fulfill its water needs, Tamil Nadu state already operates reservoirs outside the state. This causes specific problems, as is illustrated by a recent interstate case at the Supreme Court of India [31]: Tamil Nadu state leases and operates Mullaperiyar dam in Kerala. Kerala was concerned about the earthquake-safety of the dam and enacted a state law to limit the reservoir level. In view of the consequently unmet water needs of Tamil Nadu, in 2014 the Court declared the Kerala state law as unconstitutional.

Increasing the capacity of existing reservoirs was the most economical of the considered solutions and it was generally accepted. However, stakeholders were aware that for reservoirs there is a need for regulations that consider the local situations: Vulnerable water bodies might need a higher protection than guaranteed by the national standards. A notorious example, for 15 years in courts, was the Orathupalayam dam project to use water from Noyyal River for irrigation, where five years after its completion in 1992, heavy water pollution from textile industry forced farmers to give up irrigation [32].

Groundwater recharge by check dams was the second most expensive option, but it was generally accepted and it is widely used. Conflicts about land acquisition plans may hinder the realization of such large scale infrastructure projects. This is exemplified by the delay of the construction of the Thirukandalam check dam [33]. For although landowners benefit substantially from check dams by increased yields [34], farmers fear receiving insufficient compensation for arable land that is used for such projects. Also, the survey confirmed that stakeholders were aware of the need to hear farmers, when formulating water policies (see point 2 in Section 5.4).

In terms of unit costs, infiltration ponds were second best with respect to unit costs. While the acceptance was not as clear as for the other options (see Figure 3), stakeholder representatives at the second workshop (about infiltration ponds) supported the idea to construct thousands of infiltration ponds in the rural areas surrounding Chennai (point 2 in Table 4). Farmers may at first not understand 
why they should give up arable land and spend money to build such ponds (just to secure the water supply of Chennai). Stakeholder representatives were aware of this problem and they approved the idea that the government should support the farmers in building infiltration ponds (Table 5 and point 10 in Table 4). Later on, the farmers should operate and maintain them without public support (points 14 and 19 in Table 4). Thereby, the implementation of infiltration ponds may also benefit from the observed high acceptance for RWH. Accordingly, infiltration ponds are small structures comparable to RWH structures and farmers will benefit from the aquifer recharge. Media reports [35] further emphasized that farmers may generate additional income from aqua-cultures (with risks for water quality).

Stakeholder representatives at the second workshop were not so critical about existing laws (many are used to apply them in administration and courts) and considered that current laws would support infiltration ponds (point 3 in Table 4).

However, in view of the workshop discussions, the majority, and also the project team, had critical views about the inadequacy of current groundwater laws and regulations (point 3 in Section 5.4). An example for the ineffectiveness of existing laws was the still applied national Easement Act of 1882 vesting owners of land with ownership of groundwater, irrespective of the rights of neighbors or public interests in groundwater preservation. Thereby, the interests of neighbors in water de facto have not been framed as legal entitlements or obligations. Further, national agencies (CGWB, CPCB) in charge of the implementation of national policies may not really influence actual decision making, as they tend to approve projects, which receive a "no objection certificate" from state agencies [36]. Yet, the stakeholder representatives considered that the national government should indeed have only a minor role for groundwater conservation, below state governments in importance (point 1 in Section 5.4).

For the specific problem of groundwater extraction, more than $75 \%$ of stakeholder representatives acknowledged the need to better regulate it and they supported the idea that a state authority should be in charge of MAR (points 4 and 6 in Section 5.4). Currently, different agencies of the government appear to act in an uncoordinated manner and without an integrated perspective about MAR [11]. For example, the water bodies and channels are not governed by CMWSSB, and neither are the temple tanks, which could serve as MAR structures. Another issue for the workshop was ineffective governance of groundwater, as commercial operators extract it unlawfully throughout the city.

The survey also identified a communication problem, illustrated by the lack of a common understanding of key criteria, such as health. A cluster analysis confirmed this lack of a common vision: While amongst 50 stakeholder representatives, 22 "cluster respondents" with similar preferences could be identified (Figure 3), the other $56 \%$ of respondents were almost idiosyncratic and perhaps unfavorable to MAR; e.g., the "typical non-cluster respondent" was indifferent or negative with respect to check dams.

\section{Conclusions}

Groundwater is an important source of domestic water supply in Chennai during the regular droughts and the peri-urban villages depend completely on groundwater. As agriculture and industry have been overexploiting groundwater, which is evident from the lowering of the water table and the 
intrusion of seawater, more effective instruments would be needed to control the extraction of groundwater and the use of water.

The paper investigated several feasible approaches, amongst them two MAR options, namely to build large check dams or many small infiltration ponds.

For the considered options, urban RWH is widely accepted and already mandatory, but stakeholders reported ineffective monitoring. Thus, better enforcement could make RWH more effective and better define the impact.

As to non-structural policy instruments, stakeholders identified them with water pricing and did not accept them.

Desalination plants and reverse osmosis of brackish water are too costly solutions to cover the basic demand, and consumers may not accept them.

Building new reservoirs for additional water or building check dams for groundwater recharge are costly, too, and in similar projects conflicts about land acquisition have caused substantial delays.

For the same reason, infiltration ponds could meet resistance, as thousands of ponds would be needed, but there is no legislation that would make them mandatory.

Further, for the implementation of infiltration ponds there is a coordination problem, as it would have not much effect, if only a few farmers would build small infiltration ponds: About 500 ponds would correspond to a small check dam and 10,000 to a large one. Thus, farmers would face costs, the groundwater table might barely rise, and if it rises, then farmers without infiltration ponds would be free-riders that benefit as well.

From these considerations it follows:

- In the short term the most economical solution to secure water supply appears to be the enlargement of existing reservoirs. This solution is also generally accepted.

- In the long term, infiltration ponds, which are the second most economical solution, are an alternative that most stakeholder representatives would accept. However, a coordination problem needs to be resolved.

- All other options are already implemented (RWH; also most planned check dams along Arani and Kortallai Rivers are realized) or significantly more costly or not acceptable for most stakeholders.

To solve the coordination problem, stakeholder representatives support the idea to establish an authority in the state for licensing groundwater extraction and overseeing MAR. Accordingly, the establishment of a state authority responsible for groundwater governance and MAR (TNWRRA) would support the legal and policy measures needed to implement MAR structures. Thus, in this respect, stakeholders basically support the National Water Policies, where such instruments have been proposed. Of course, stakeholders did not envision merely another organization amongst the many existing ones, but wanted to see all groundwater responsibilities amalgamated.

\section{Acknowledgments}

Co-funding to the collaborative project "Enhancement of natural water systems and treatment methods for safe and sustainable water supply in India-Saph Pani" (www.saphpani.eu) from the 
European Commission within the Seventh Framework Programme (grant agreement number 282911) is gratefully acknowledged.

\section{Author Contributions}

All authors are equally responsible for the conception of the paper. The CEMDS team was responsible for the data analysis and legal analyses, the Anna University team for the factual information and all Indian authors for the information acquisition from the workshops.

\section{Conflicts of Interest}

The authors declare no conflict of interest.

\section{References and Notes}

1. Starkl, M.; Brunner, N.; Zhong, Y.; Li, P.; Wang, Y.; Ericson, M. Overcoming barriers for the management of scarce water resources in Northern China. Water Policy 2014, in print.

2. Hardin, G. The Tragedy of the Commons. Science 1968, 162, 1243-1248.

3. Ostrom, E. Governing the Commons: The Evolution of Institutions for Collective Action; University Press: Cambridge, UK, 1990.

4. Shah, T. Towards a Managed Aquifer Recharge strategy for Gujarat, India: An economist's dialogue with hydro-geologists. J. Hydrol. 2014, 518, 94-107.

5. Sharma, S. Managed Aquifer Recharge: Introduction; UNESCO-IHE: Delft, The Netherlands, 2011.

6. Gale, I.; Dillon, P. Strategies for Managed Aquifer Recharge in Semi-Arid Areas; UNESCO-IHP: Paris, France, 2005.

7. Potter, E. Recycling Practice: Rainwater harvesting in Chennai, India, and the politics of water provision. In Recycling Cities; Inter-Asia Roundtable: Singapore, 2011; pp. 79-95.

8. Essl, L.; Starkl, M.; Kimothi, P.C.; Sandhu, C.; Grischek, T. River bank filtration and managed aquifer recharge as alternative water supply technologies for India: SWOT analysis. Water Sci. Technol. Water Supply 2014, 14, 690-697.

9. Llamas, R.; Back, W.; Margat, W. Groundwater Use: Equilibrium between Social Benefits and Potential Environmental Costs. Appl. Hydrol. 1992, 1, 3-14.

10. Jain, S.K. Harnessing the Managed Aquifer Recharge Potential for Sustainable Groundwater Management in India. Water Energy Int. 2012, 69, 32-38.

11. Sakthivel, P.; Amirthalingam, S.; Starkl, M. A study on law relating to groundwater recharge in India. Rostrum's Law Rev. 2013, 1, 83-101.

12. Douglas, I. Peri-urban ecosystems and societies: Transitional zones and contrasting values. In The Peri-Urban Interface; McGregor, D., Simon, D., Thompson, D., Eds.; Earthscan: London, UK, 2006; pp. 18-29.

13. Starkl, M.; Brunner, N.; López, E; Martínez-Ruiz, J.L. A planning-oriented sustainability assessment framework for peri-urban water management in developing countries. Water Res. 2013, 47, 7175-7183. 
14. Sakthivel, P.; Elango, L.; Amirthalingam, S.; Pratap, C.E.; Brunner, N.; Starkl, M.; Thirunavukkarasu, M. Managed Aquifer Recharge: The Widening Gap between Law and Policy in India. In Proceedings of the IWA World Water Congress, Lisbon, Portugal, 21-26 September 2014.

15. Brocklehurst, C.; Pandurangi, A.; Ramanathan, L. Tariff Subsidies in South Asia: Tariff Structures in Six South Asian Cities: Do They Target Subsidies Well? In Water Tariffs and Subsidies in South Asia; The World Bank: Washington, DC, USA, 2002.

16. Gao, L.; Connor, J.D.; Dillon, P. The economics of groundwater replenishment for reliable urban water supply. Water 2014, 6, 1662-1670.

17. Parimala Renganayaki, S.; Elango, L. A Review on Managed Aquifer Recharge by Check Dams: A Case Study near Chennai, India. Int. J. Res. Eng. Technol. 2013, 2, 416-423.

18. Nair, I.; Parimala Renganayaki, S.; Elango, L. Identification of seawater intrusion by $\mathrm{Cl} / \mathrm{Br}$ ratio and mitigation through Managed Aquifer Recharge in aquifers north of Chennai, India. J. Groundw. Res. 2013, 2, 155-162.

19. Isaac, S.; Michael, W.B. Handbook in Research and Evaluation; EDITS: San Diego, CA, USA, 1995.

20. Jamil, H.; Kumar, P.; Ismail, S.; Roy, R. Interstate Water Dispute and Federalism: Governance of Interstate River Water in India. Civ. Environ. Res. 2012, 2, 11-16.

21. Butterworth, J.; Ducrot, R.; Faysse, N.; Janakarajan, S. Peri-Urban Water Conflicts: Supporting Dialogue and Negotiation; International Water and Sanitation Centre: Delft, The Netherlands, 2007.

22. There were 11 exceptions from the two major groups: Two cluster respondents (S01 and T24 in Figure 4) were indifferent about desalination; they had high acceptance for check dams, but (other than non-cluster respondents with similar preferences) only with "high potential". Three non-cluster respondents had low acceptance for desalination, but (other than cluster respondents) they ranked health at three to five. Six non-cluster respondents were indifferent about sanitation and they accepted check dams, but (differently from cluster respondents) with "very high potential".

23. Mefalopulos, P.; Kamlongera, C. Participatory Communication Strategy Design: A Handbook; FAO: Rome, Italy, 2004.

24. Madras High Court. Pachai Perumal v District Collector of 08.07.2011; Madras High Court: Chennai, India, 2011.

25. Dolnicar, S.; Schäfer, A.I. Desalinated versus recycled water: Public perceptions and profiles of the accepters. J. Environ. Manag. 2009, 90, 888-900.

26. Bustamante, R. The water war: resistance against privatization of water in Cochabamba, Bolivia. Revista de Gestión Del Agua en América Latina 2004, 1, 37-46.

27. Harris, L.M.; Roa-Garcia, M.C. Recent waves of water governance: Constitutional reform and resistance to neo-liberalization in Latin America (1990-2012). Geoforum 2013, 50, 20-30.

28. Flynn, S.; Chirwa, D.M. The Constitutional Implications of Commercializing Water in South Africa. In The Age of Commodity: Water Privatization in Southern Africa; McDonald, D., Ruiters, G., Eds.; Earthscan: London, UK, 2005; pp. 59-77.

29. Walker, G. Environmental justice, impact assessment and the politics of knowledge. Environ. Impact Assess. Rev. 2010, 30, 312-318.

30. Madras High Court. K.P. Vijayan v District Revenue Officer of 25.03.2008; Madras High Court: Chennai, India, 2008. 
31. Supreme Court of India. Tamil Nadu v Kerala of 07.05.2014; Supreme Court of India: Delhi, India, 2014.

32. Madras High Court. M. Ramasamy v Noyyal River Ayacutdars Protection Association of 01.11.2012; Madras High Court: Chennai, India, 2012.

33. Lakshimi, K. Long-Overdue Check Dam Project to Finally Begin. The Hindu, 4 June 2013.

34. Sen, S.; Shah, A.; Kumar, A. Watershed Development Programs in Madhya Pradesh, Present Scenario and Issues for Convergence. In Forum for Watershed Research and Policy Dialogue; Institute of Development Research: Pune, India, 2007.

35. Renganathan, L. More Farm Ponds in Delta Will Shore up Water Resources. The Hindu, 26 August 2014.

36. Koonan, S. Groundwater-Legal Aspects of Plachimada Dispute. In Water Governance in Motion: Towards Socially and Environmentally Sustainable Water Laws; Cullet, P., Gowlland-Gualtieri, A., Madhav, R., Usha, R., Eds.; Cambridge University Press India: New Delhi, India, 2010.

(C) 2014 by the authors; licensee MDPI, Basel, Switzerland. This article is an open access article distributed under the terms and conditions of the Creative Commons Attribution license (http://creativecommons.org/licenses/by/4.0/). 